\title{
Thermal performance and cost analysis of mortars made with PCM and different binders
}

\author{
Sandra Cunha ${ }^{\mathrm{a}, *}$, José B. Aguiar ${ }^{\mathrm{a}}$, António Tadeu ${ }^{\mathrm{b}}$ \\ ${ }^{a}$ University of Minho, Department of Civil Engineering, Campus de Azurém, 4800-058 Guimarães, Portugal \\ ${ }^{\mathrm{b}}$ University of Coimbra, Rua Luís Reis Santos - Pólo II, 3030-788 Coimbra, Portugal
}

\section{H I G H L I G H T S}

- PCM mortars based in different binders were used to study the thermal behavior.

- The thermal behavior and cost analyses were evaluated based in Portuguese climate.

- The PCM mortars reveal higher thermal regulation and lower energy needs.

- The PCM mortars showed a decrease of the cost related to the energy consumption.

\section{A R T I C L E I N F O}

Article history:

Received 6 October 2015

Received in revised form 30 May 2016

Accepted 21 June 2016

Available online 9 July 2016

\section{Keywords:}

Mortars

Phase change materials

Microstructure

Thermal performance

Cost analysis

\begin{abstract}
A B S T R A C T
The high energetic consumption is one of the biggest concerns of modern society. The incorporation of phase change materials (PCM) in construction materials allows regulates the temperature inside the buildings. The main objective of this study was the characterization of the thermal performance of PCM mortars based in different binders. It was possible to observe that the incorporation of PCM in mortars leads to a decrease of the maximum temperatures, increase of the minimum temperatures, significant lag time delay, reduction of the heating and cooling needs, and consequent decrease of the cost of HVAC systems operation, for all tested seasons.
\end{abstract}

(c) 2016 Elsevier Ltd. All rights reserved.

\section{Introduction}

The energy is an essential factor for economic and social development, and for improvement of the life quality in all countries. Energy sources can be non-renewable or renewable. Nonrenewable energy sources possess the possibility to deplete over time, such as petroleum, coal and natural gas. Renewable energy sources represent inexhaustible resources such as biomass, hydro, wind, geothermal and solar.

The economic growth of the countries in the last years has caused rapid increase in energy consumption, which affects the population and the environment [1]. The energy efficiency of buildings is now one of the main objectives of regional, national and international energy management [2]. The buildings are one of the leading sectors in energy consumption at developed countries. In the European Union the buildings are responsible for $40 \%$

\footnotetext{
* Corresponding author.

E-mail addresses: sandracunha86@gmail.com (S.Cunha), aguiar@civil.uminho.pt (J.B. Aguiar), tadeu@dec.uc.pt (A. Tadeu).
}

of energy consumption and $40 \%$ of carbon dioxide $\left(\mathrm{CO}_{2}\right)$ emission to the atmosphere. Currently, the European Union has the 2020 energy strategy that proposes the reduction of $20 \%$ in primary energy consumption and $\mathrm{CO}_{2}$ emissions and the increase of $20 \%$ in energy consumption coming from renewable sources [3].

In a sustainable approach, buildings should be designed to ensure the thermal comfort of the occupants throughout the year, with minimum auxiliary energy for heating and cooling. In nonsustainable approaches, buildings are increasingly dependent on heating and cooling systems to ensure thermal comfort inside, resulting in the increase in energy consumption and greenhouse gases emissions. Consequently, there is also an increase in building utilization costs, caused by the impact of HVAC systems operation $[2,4]$.

Every year the energy powered by the sun that reaches the entire land surface is about 10,000 times higher than the actual energy consumption per year worldwide [5]. Taking into account that the European building sector is responsible for high energetic consumptions, it is important to find a way to take advantage of the solar energy. Thus, it becomes imperative to 
obtain a constructive solution that will minimize these consumptions, improving the energetic efficiency of buildings without damaging the environment. In order to reach a solution for this problem, it is also important to define and develop strategies to displace the consumption from peaks or hours of greatest demand, to off-peak periods.

Mortars with Phase Change Materials (PCM) incorporation for interior coating can be seen as a key for solving or at minimizing, the massive energetic consumption related to buildings. These materials have the ability to reduce temperature variations due to its capability to alter its own state depending on the environmental temperature, absorbing and releasing energy into the environment. Thus, mortars doped with PCM bring social, economic and environmental benefits, demonstrating a significant contribution to a more sustainable construction. The social benefits are directly connected with the increase in thermal comfort. The environmental aspect concerns to the reduction of fossil fuels depletion related with the decrease on air conditioning equipment usage. The economic benefits are related with the reduction of energy consumption and lag time for lower demand hours [6].

Materials with incorporation of PCM can be applied in floors, walls or ceilings, as well as being an integrating part of the most complex energetic system [6]. However, the application of PCM in walls is the preferential solution to explore the potential of these materials, due to the large areas in buildings.

The PCM can be incorporated in construction materials by different methods: direct incorporation, immersion, encapsulation, shape-stabilization and form stable composite PCMs [7]. The direct incorporation is the simplest method in which PCM is directly mixed with the construction materials. In the immersion method, the construction products are dipped into the liquid PCM, absorbing the PCM by capillarity. However, the material can interfere with the hydration products and affect the mechanical and durability properties of the doped construction materials [8]. The shape-stabilized PCM can be prepared by integrating the PCM into the supporting material. The shape-stabilized PCM are mainly classified as composite PCM and are usually fabricated by embedding PCM into shape stabilization supports, such as high density polyethylene, styrene, butadiene, polymethacrylic acid, polystyrene resin, etc. [9]. There are two types of encapsulation: macroencapsulation and microencapsulation. The macroencapsulation is based in the introduction of PCM into tubes, panels or other large containers. It is usually done in containers with more than $1 \mathrm{~cm}$ diameter and presents better compatibility with the material, improving the handling in the construction [10]. The microencapsulation consists in covering PCM particles with a material, usually a polymer, commonly known as capsule, with dimensions between $1 \mu \mathrm{m}$ and $60 \mu \mathrm{m}$ [10-11]. The main advantages of this technique are related with the capability to prevent PCM leakage during phase transition, increasing its chances of incorporation into various construction materials, providing high heat transfer rate through its larger surface area and more facility to handle [7].

Some studies were published about the use of construction materials with incorporation of PCM microcapsules. Initially, the incorporation of microencapsulated PCM in gypsum plasterboard was the subject of several studies performed due to its low cost and various application possibilities [12-14]. Darkwa et al. [13] investigated the behavior of two solutions with incorporation of PCM into gypsum plasterboard. On one side, plasterboard with $12 \mathrm{~mm}$ thickness, all impregnated with PCM, was used, to compare with another situation in which they applied single plasterboard with $10 \mathrm{~mm}$ thickness, covered with $2 \mathrm{~mm}$ of PCM laminate. The PCM amount incorporated in both cases was the same. The results showed that the PCM laminate use is more efficient, since it contributed to an increase in the minimum temperature. Other solutions were also developed such as alveolar PVC panels, blocks and bricks $[15,19]$. Cabeza et al. monitored the behavior of concrete test cells, with and without addition of 5\% of PCM microcapsules. The PCM was incorporated into the concrete used on the roof, and south and west walls. During the summer and without ventilation a decrease in the maximum temperature and a time lag of $2 \mathrm{~h}$ were recorded [10].

The mortars with incorporation of PCM has been a target of study and interest for the scientific community. However, the characterization and comparison of the thermal performance of mortars based on different binders is one of the main knowledge gaps. Thus, the main objective of this work was the study of the thermal behavior and cost analysis of mortars with incorporation of phase change materials exposed to current temperatures of Portugal. Mortars made with different binders and PCM contents were developed. Microscope observations, thermal tests and cost analyses were performed in eight different compositions based in aerial lime, hydraulic lime, gypsum and cement. For each binder, mortars without PCM and with incorporation of $40 \%$ of PCM microcapsules, were tested.

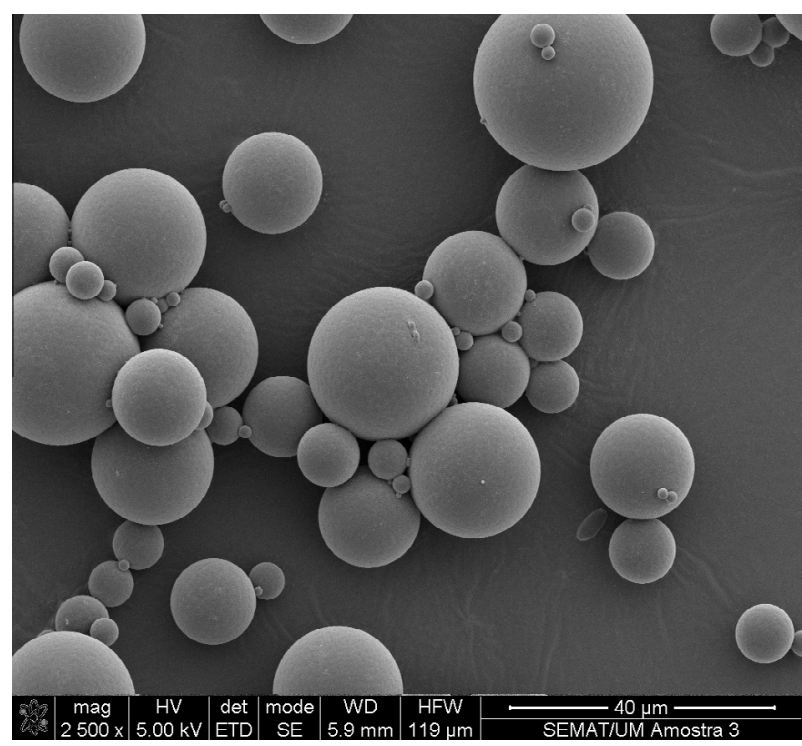

Fig. 1. Microscope observation of the polymer surface of the PCM microcapsules, enlargement of $2500 \times$.

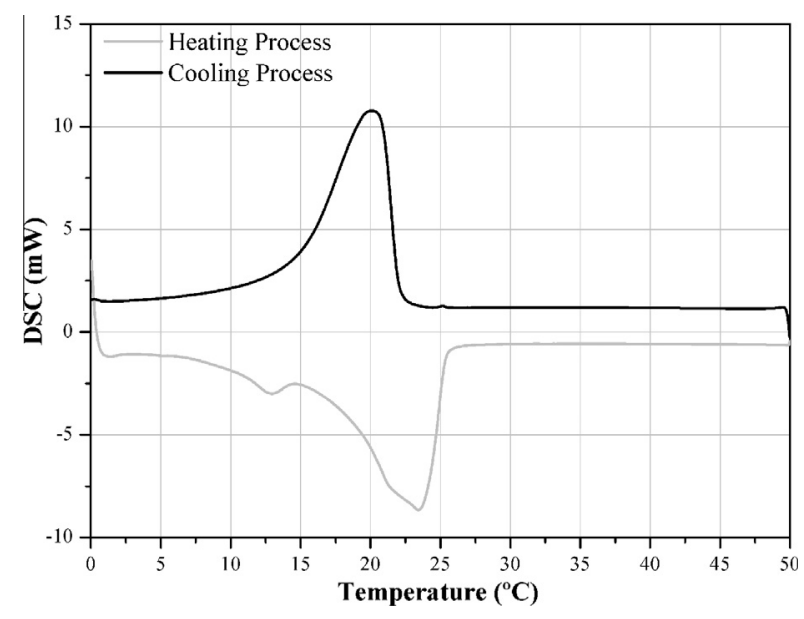

Fig. 2. DSC thermograph of the PCM microcapsules. 


\section{Experimental program}

\subsection{Materials}

The influence of adding PCM in interior coating mortars was studied. The materials selection took into account previous works [16-18]. Mortars were developed based on the following binders: aerial lime, hydraulic lime, gypsum and cement. The used aerial lime had a purity of $90 \%$ and density of $2450 \mathrm{~kg} / \mathrm{m}^{3}$. The gypsum corresponds to a traditional one, with high fineness and density of $2740 \mathrm{~kg} / \mathrm{m}^{3}$. The hydraulic lime was a natural one (NHL5), with density of $2550 \mathrm{~kg} / \mathrm{m}^{3}$. CEM II B-L $32.5 \mathrm{~N}$ cement with density of $3030 \mathrm{~kg} / \mathrm{m}^{3}$ was also used. The used superplasticizer was a polyacrylate, with density of $1050 \mathrm{~kg} / \mathrm{m}^{3}$. The used sand has an average particle size of $4399 \mu \mathrm{m}$ and density of $2600 \mathrm{~kg} / \mathrm{m}^{3}$. Based in granulometric distribution, the parameters D50, D10 and D90 were obtained. The D10 corresponds to $150 \mu \mathrm{m}$, D50 corresponds to $310 \mu \mathrm{m}$ and the D90 corresponds to $480 \mu \mathrm{m}$. Finally synthetic polyamide fibers with a length of $6 \mathrm{~mm}, 22.3 \mu \mathrm{m}$ of thickness and density of $1380 \mathrm{~kg} / \mathrm{m}^{3}$, were used.

The used PCM is composed by a wall in melamine-formaldehyde and a core in paraffin with density of $880 \mathrm{~kg} / \mathrm{m}^{3}$ and enthalpy of $147.9 \mathrm{~kJ} / \mathrm{kg}$ (Fig. 1). The transition temperature was evaluated with a Differential Scanning Calorimetry (DSC), using standard aluminum $40 \mu \mathrm{l}$ crucibles. The temperatures and latent heats of the solidification and melting processes have been determined with a scanning speed of $0.1^{\circ} \mathrm{C} / \mathrm{min}$, in both cooling and heating. One test was performed for each sample and the crucible has undergone three cooling/heating complete cycles. The PCM exhibits a transition temperature of $24^{\circ} \mathrm{C}$ in the heating cycle and $21^{\circ} \mathrm{C}$ in the cooling cycle (Fig. 2). The PCM fabrication process is polycondensation by addition and the material is commercialized by the Devan Chemicals, with the commercial name of Mikathermic D24. In order to determine the dimensions of PCM microcapsules, granulometry tests were performed using a laser particle size analyzer. It was possible to observe a particle size distribution between 5.8 and $339 \mu \mathrm{m}$, with $80 \%$ of particle size between 10.4 and $55.2 \mu \mathrm{m}$ and an average particle size of $44 \mu \mathrm{m}$.

\subsection{Compositions of mortar mixtures}

Table 1 presents the compositions studied. These have different PCM contents and different binders. The PCM contents were fixed in $0 \%$ and $40 \%$ of aggregate mass. A previous study [18] showed that the mortars with $40 \%$ of PCM have adequated physical and mechanical properties.

Table 1

Mortars formulation $\left(\mathrm{kg} / \mathrm{m}^{3}\right)$.

\begin{tabular}{|c|c|c|c|c|c|c|c|}
\hline Composition & Binder & & Sand & PCM & SP & Fibers & Water/Binder \\
\hline AL500-0PCM & Aerial Lime & 500 & 1447.2 & 0 & 15 & 0 & 0.45 \\
\hline AL800-40PCM-F & Aerial Lime & 800 & 425.2 & 170.1 & 24 & 8 & 0.36 \\
\hline HL500-0PCM & Hydraulic lime & 500 & 1351.1 & 0 & 15 & 0 & 0.54 \\
\hline HL500-40PCM-F & Hydraulic lime & 500 & 567.2 & 226.9 & 15 & 5 & 0.62 \\
\hline CEM500-0PCM & Cement & 500 & 1418.8 & 0 & 15 & 0 & 0.55 \\
\hline CEM500-40PCM-F & Cement & 500 & 622.2 & 248.8 & 15 & 5 & 0.59 \\
\hline G500-0PCM & Gypsum & 500 & 1360.4 & 0 & 15 & 0 & 0.56 \\
\hline G500-40PCM-F & Gypsum & 500 & 535.8 & 214.3 & 15 & 5 & 0.70 \\
\hline
\end{tabular}

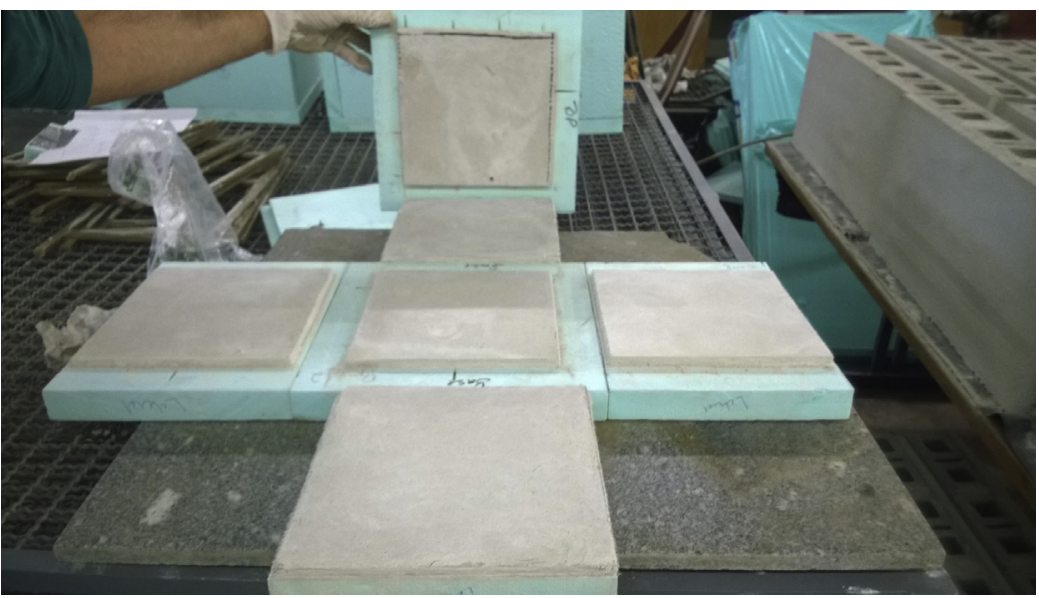

Fig. 3. Small-scale test.

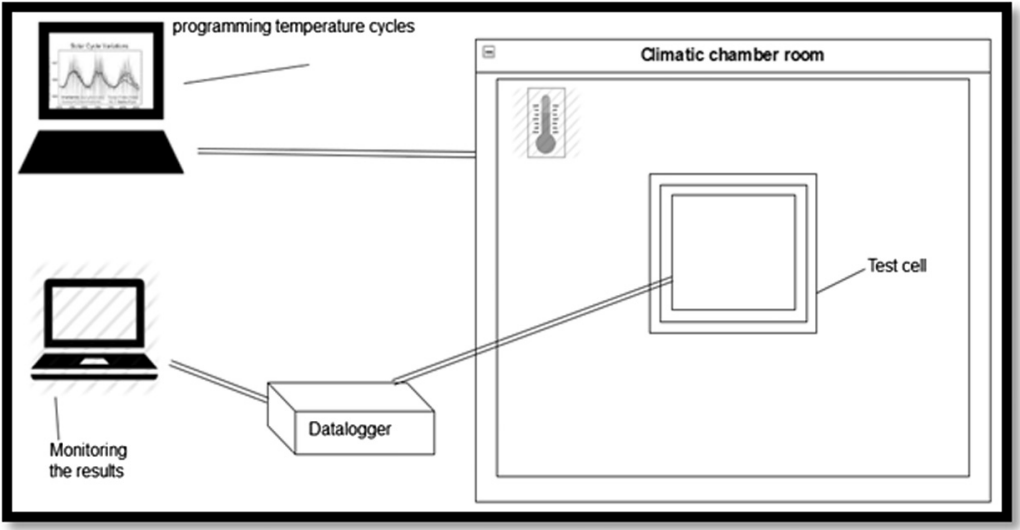

Fig. 4. Setup of the thermal tests, adapted from Kheradmand et al. [21]. 


\subsection{Test procedures}

Workability tests were performed based on the flow table method stated by the European standard EN 1015-3, with the main goal to verify the adequated of application of the developed mortars [19]. The resulting value within the test was considered only when equal to $200 \pm 5 \mathrm{~mm}$.

For the determination of flexural and compressive strengths of mortars, 3 prismatic specimens were produced with dimensions of $40 \times 40 \times 160 \mathrm{~mm}^{3}$, according to the standard EN 1015-11 [20]. After the preparation, all the specimens were stored during 7 days into polyethylene bags and subsequently placed in the laboratory at regular room temperature (about $22^{\circ} \mathrm{C}$ ) for 21 days. The flexural and compressive tests were performed with load control at speeds of $50 \mathrm{~N} / \mathrm{s}$ and $150 \mathrm{~N} / \mathrm{s}$, respectively.

The microstructure observation of developed mortars was performed using a scanning electron microscope. For each composition, 2 cylindrical specimens with diameter and height of approximately $1 \mathrm{~cm}$ were prepared. After its preparation,

Table 2

Flexural and compressive strengths, and classification based in the NP EN 998-1:2013.

\begin{tabular}{llcl}
\hline Composition & $\begin{array}{l}\text { Flexural strength } \\
(\mathrm{MPa})\end{array}$ & $\begin{array}{l}\text { Compressive } \\
\text { strength (MPa) }\end{array}$ & $\begin{array}{l}\text { Classification NP } \\
\text { EN 998-1:2013 }\end{array}$ \\
\hline AL500-0PCM & 0.65 & 1.90 & CSII \\
AL800-40PCM-F & 1.62 & 3.46 & CSII \\
HL500-0PCM & 2.24 & 8.76 & CS IV \\
HL500-40PCM-F & 1.61 & 3.48 & CSII \\
CEM500-0PCM & 7.23 & 29.05 & CS IV \\
CEM500-40PCM-F & 3.80 & 10.69 & CS IV \\
G500-0PCM & 4.77 & 11.78 & CS IV \\
G500-40PCM-F & 1.58 & 2.49 & CSII \\
\hline
\end{tabular}
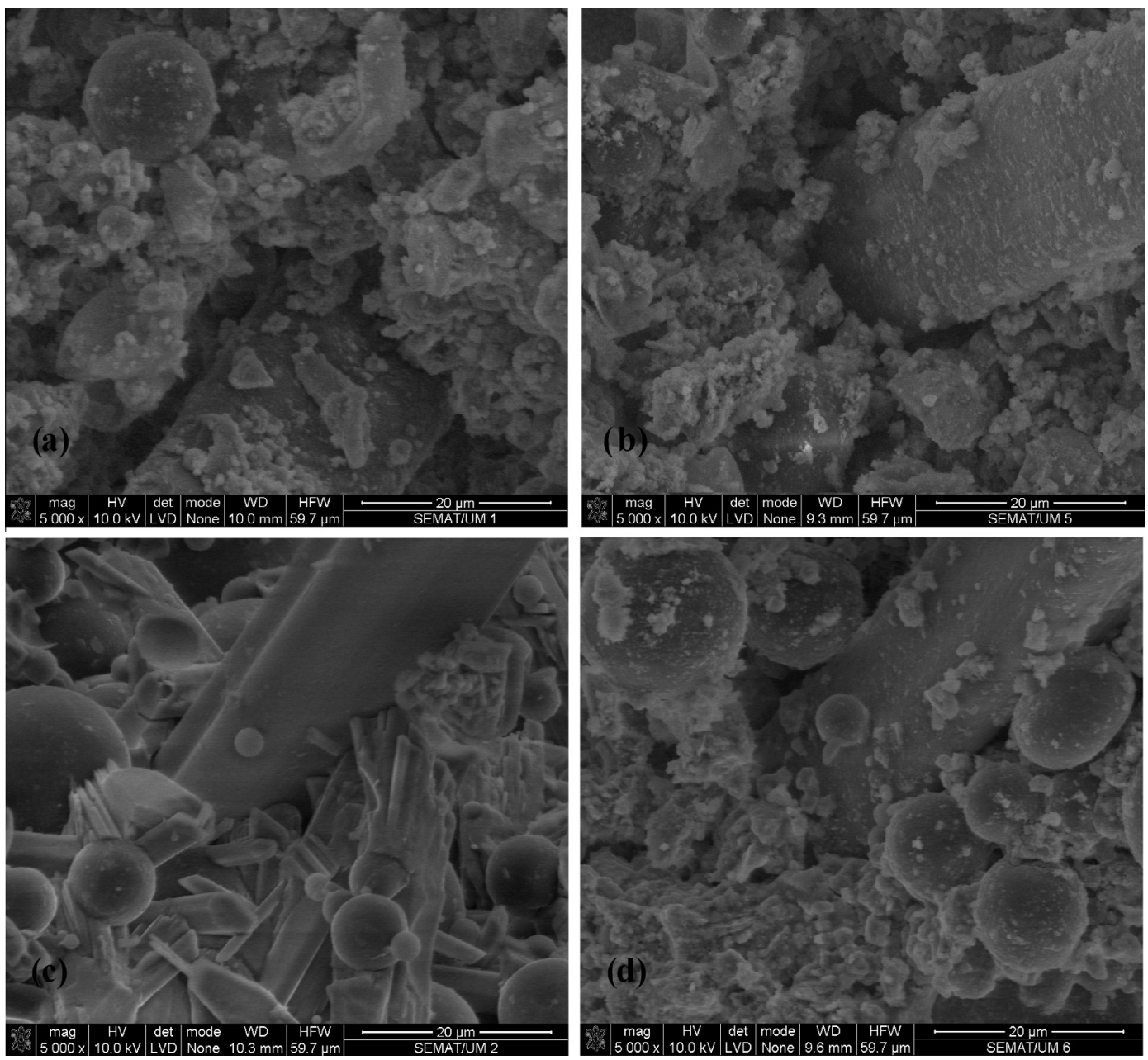

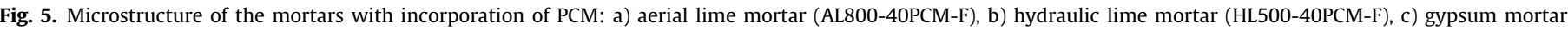
(G500-40PCM-F), d) cement mortar (C500-40PCM-F). all the specimens were stored during 7 days into polyethylene bags and subsequently placed in the laboratory at regular room temperature (about $22^{\circ} \mathrm{C}$ ) for 21 days.

The thermal behavior was tested in a climatic chamber, with temperature laws representative of each season of the year. Thus, the thermal behavior of the developed mortars in winter, summer, spring and autumn, was analyzed. The temperature laws were fixed based on climatic data collected at the weather station installed on the University of Minho campus in Guimarães, Portugal.

For each composition, a small-scale test cell was made with an insulating material (extruded polystyrene) with $3 \mathrm{~cm}$ of thickness and coated on the inside with a mortar layer of $1 \mathrm{~cm}$ (Fig. 3). These cells had dimensions of $200 \times 200 \times 200 \mathrm{~mm}^{3}$. One thermocouple was placed inside each small-scale cell, in the center zone, at height of $10 \mathrm{~cm}$ from the cell base. Each small-scale test cell was placed inside a controlled climatic chamber provided with thermocouples for test temperature control. Each thermocouple used during the tests was connected to a data acquisition system of high sensibility (AGILENT 34970A), recording the temperature inside the climatic chamber and small-scale test cells at every minute. Type $\mathrm{K}$ thermocouples were used. Fig. 4 shows the setup of the thermal tests.

During these tests, the PCM reached the phase transition (between 21 and $24^{\circ} \mathrm{C}$ ) storing and releasing energy from the environment. The aim was to measure

\section{Test results and discussion}

\subsection{Workability}

The workability tests showed that the incorporation of $40 \%$ of PCM leads to an increase in water content higher than $8 \%$ for all tested binders with the exception of aerial lime mortars (Table 1). The decrease of water content in aerial lime mortar can be the impact of the PCM incorporation in interior temperatures of the small-scale cell. 
explained by the presence of a higher superplasticizer content related with the presence of higher binder dosage to obtain an adequate mechanical classification (CSII) of all used mortars [22]. On the other hand, the increase in water content observed for the hydraulic lime, gypsum and cement mortars can be explained by the reduced particle dimension of the used PCM microcapsules.

\subsection{Flexural and compressive behavior}

Table 2 shows a decrease in the flexural and compressive strengths caused by the introduction of PCM microcapsules into mortars, except for aerial lime based mortars. This behavior can be justified by the water content variations, caused by the fineness of the used PCM microcapsules and the superplasticizer content.
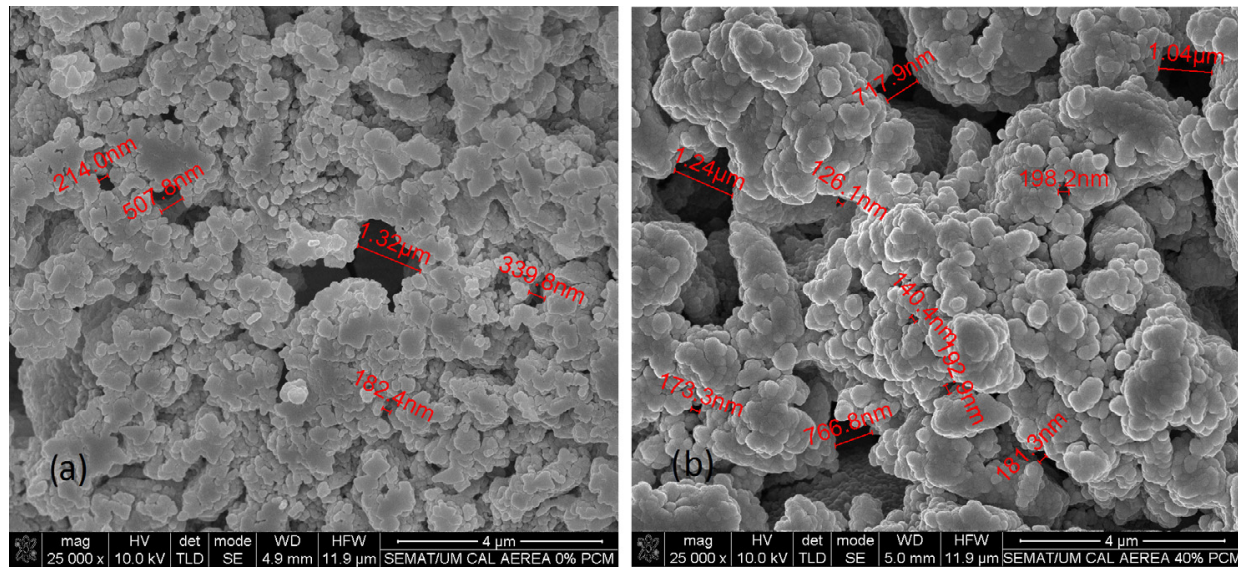

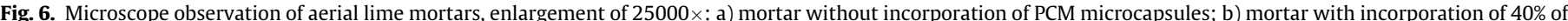
PCM microcapsules.
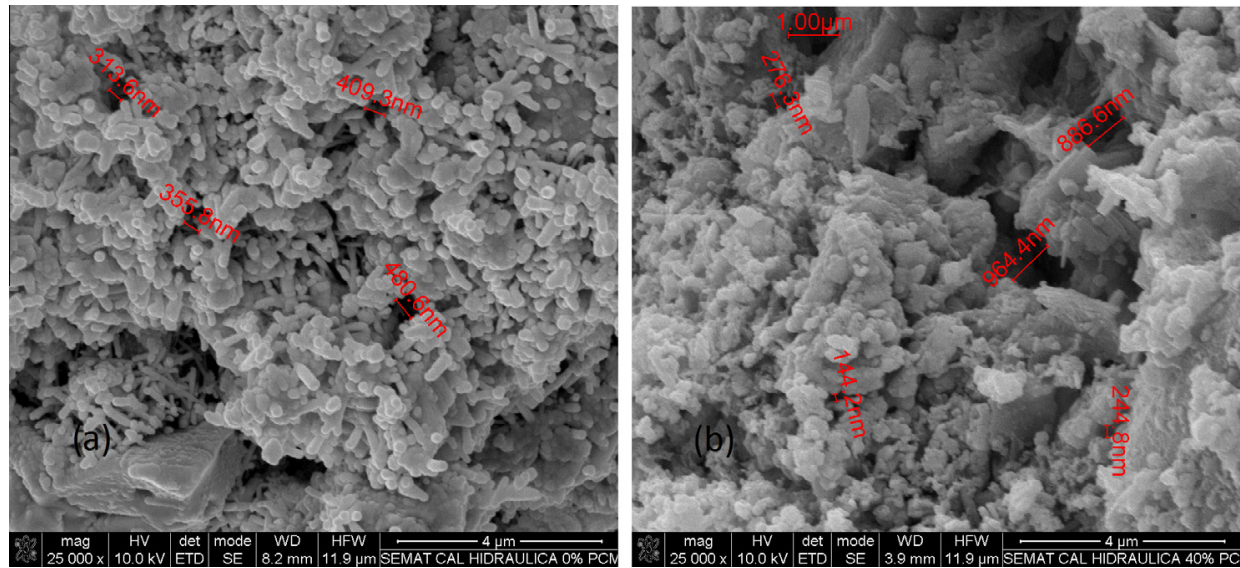

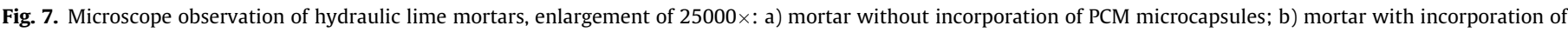
$40 \%$ of PCM microcapsules.
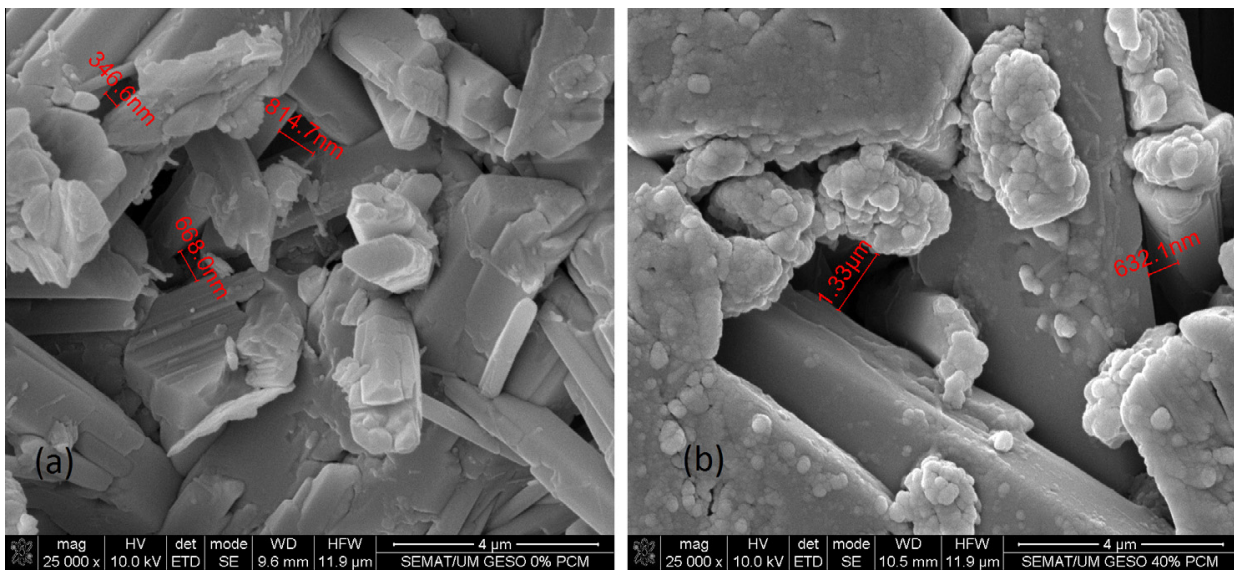

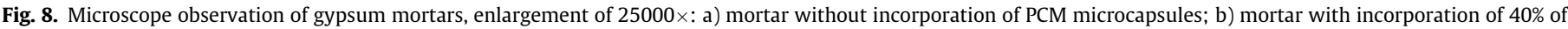
PCM microcapsules. 
It is important to note that taking into account the future application in the construction sector, the obtained mortars should have a minimum classification of CSII based on the compressive strength, according to the standard NP EN 998-1 [22], as a premise of this work.

The incorporation of PCM microcapsules decreased the flexural strength more than $28 \%$ and the compressive strength at least $60 \%$ when compared with the reference mortar. However, in the aerial lime based mortars it was possible to observe an increase of $150 \%$ in the flexural strength and an increase of $82 \%$ in the compressive strength when compared with the reference mortar (Table 2). The behavior of aerial lime mortars can be justified by the use of higher binder content, necessary to obtain the minimum classification. The aerial lime mortars with lower binder content and $40 \%$ of PCM presented an inferior classification than required.
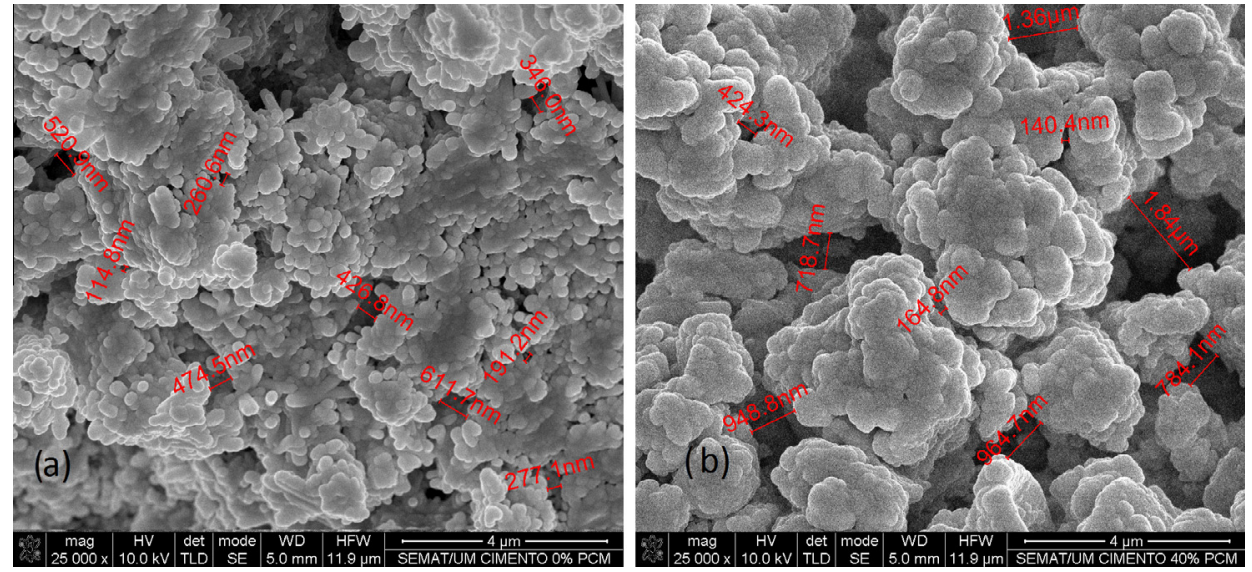

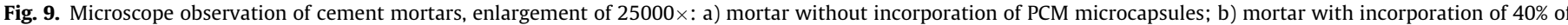
PCM microcapsules.
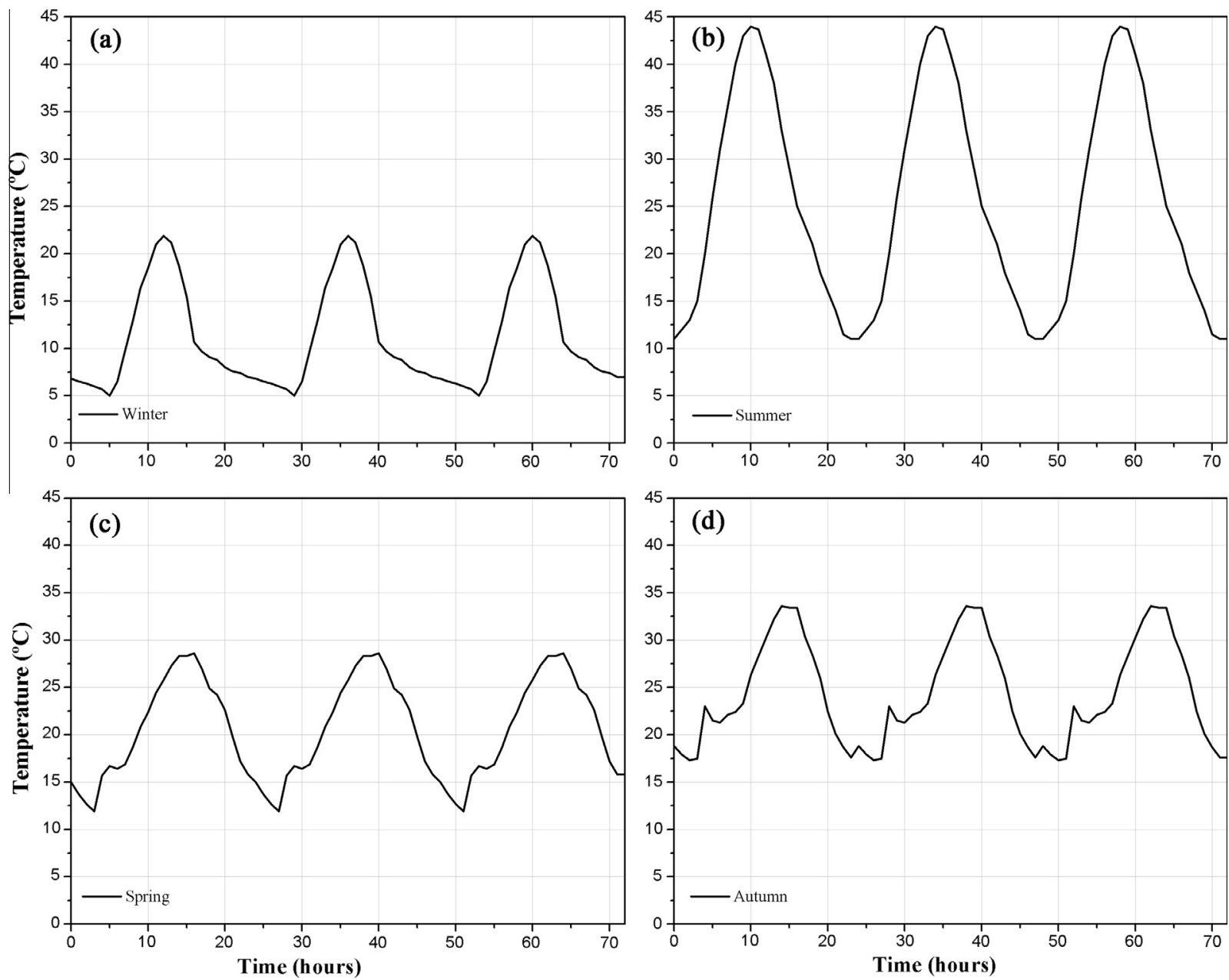

Fig. 10. Temperature laws used to simulate the different seasons of the year: a) winter; b) summer; c) spring; d) autumn. 
Table 2 also shows that the PCM incorporation leads to a lower classification, however the minimum classification of CSII is always achieved.

\subsection{Microstructure}

The scanning electron microscope observations were performed to evaluate the existence of possible incompatibilities between different materials present in mortars. Fig. 5 shows the microstructure of aerial lime, hydraulic lime, gypsum and cement based mortars with incorporation of $40 \%$ of PCM microcapsules. These observations reveal a good connection between the different materials (PCM, fibers, aggregate and binder) evidenced by the absence of cracks in the microstructure of the mortars developed. It can be seen that the PCM microcapsules present a good and homogeneous distribution in the matrix. The PCM showed a good integrity, without signs of rupture or damages, demonstrating that the microcapsules can adequately resist to the process of mortar mixing, application and curing.

Other observations were performed to evaluate the pore size and distribution in the different mortars. Figs. 6-9 show the changes observed in the pore distribution on the mortars with the incorporation of $40 \%$ of PCM. The microporosity increased with the incorporation of $40 \%$ of PCM. Higher dimensions micropores were observed in the mortars with incorporation of PCM compared with the reference mortar. The internal structure of the reference mortars is more compact compared with the mortars with PCM that exhibit biggest pores. The presence of higher microposity can be explained by the higher water content of the mortars doped with PCM, due to the reduced particle size of the incorporated material.

The gypsum mortars exhibited higher dimensions pores (Fig. 8), due to the higher water content. On the other hand, the aerial lime mortars showed micropores with lower dimensions (Fig. 6). This behavior can be explained by the presence of lower water content and higher superplasticizer content.

\subsection{Thermal behavior}

It is known that the external temperature significantly influences the PCM behavior [23-25]. Thus, based on weather data, a tests campaign was conducted with the aim to evaluate the thermal behavior of mortars with incorporation of PCM in a current climate of northern Portugal region.

During the tests, all seasons of the year were evaluated. For the spring situation, the analyzed temperature range was between $12^{\circ} \mathrm{C}$ and $29^{\circ} \mathrm{C}$. In the autumn, the considered temperatures were between $17^{\circ} \mathrm{C}$ and $34^{\circ} \mathrm{C}$. The summer situation was evaluated with temperature range with a minimum of $11^{\circ} \mathrm{C}$ and a maximum of $44^{\circ} \mathrm{C}$. To simulate the winter, the temperature range presented a minimum of $5{ }^{\circ} \mathrm{C}$ and a maximum of $22^{\circ} \mathrm{C}$. For the winter situation, the evaluation of the PCM effect was not possible because the PCM melting point was not achieved. In order to evaluate in detail this
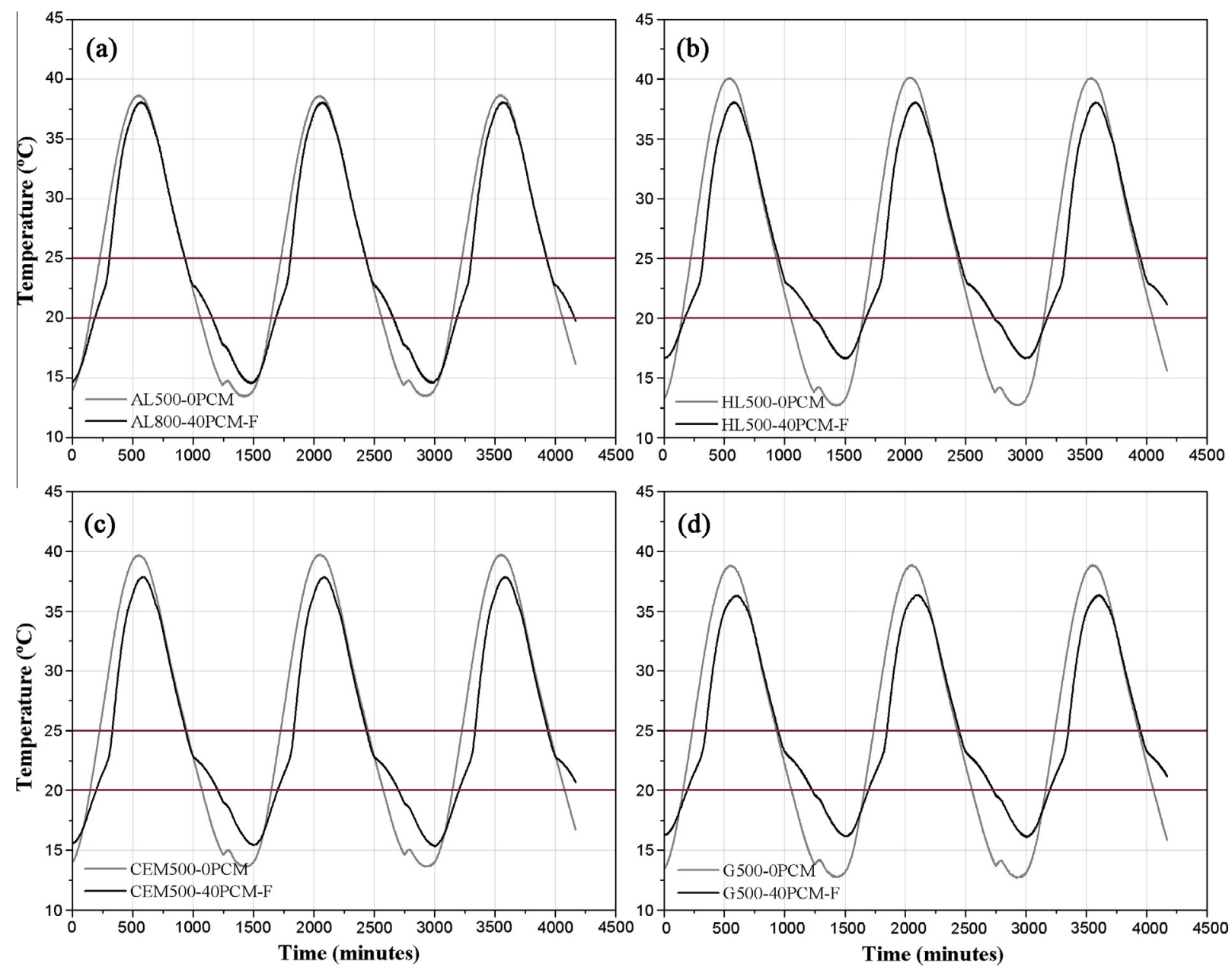

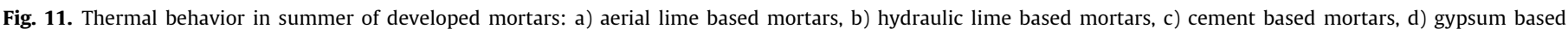
mortars. 
situation, it would be necessary to use an auxiliary heating system to increase the temperature till the PCM melting point.

Fig. 10 shows the temperature laws used to simulate a typical summer, winter, spring and autumn. Each season was simulated with three cycles. Each one was with the duration of $24 \mathrm{~h}$.

Figs. 11-13 show the behavior of the developed mortars in a summer, spring and autumn situation. In each season, mortars based in aerial lime, hydraulic lime, cement and gypsum, with and without PCM, were analyzed.

Fig. 11 shows the thermal behavior of the developed mortars in a summer situation. It was observed the existence of temperatures above $25^{\circ} \mathrm{C}$ and below $20^{\circ} \mathrm{C}$. Thus, it was identified that there are heating and cooling needs, during the summer. Fig. 12 shows the thermal behavior of the mortars during the spring. It was verified the absence of cooling needs, since the maximum temperature, for the PCM mortars, is lower than $25^{\circ} \mathrm{C}$. Fig. 13 shows the thermal behavior during the autumn, revealing that the PCM mortars did not present heating needs, since the minimum temperatures were higher than $20^{\circ} \mathrm{C}$.

For all tests, it was observed that when the temperature achieves the range between $20^{\circ} \mathrm{C}$ and $25^{\circ} \mathrm{C}$, the PCM phase change occurs and the thermal behavior of the PCM mortar begins to evolve in a different way from the temperature curve of the reference mortars. In all tests, the positive effect of the PCM was verified, since cells with PCM did not reach such extreme temperatures as the reference test cell ( $0 \%$ PCM), the inside temperature remains stable for a longer period. This mean a shortest operation time of heating and/or cooling systems when the PCM mortars are used and an effective energy saving can be achieved.

Regarding the summer situation (Fig. 11), it was observed that in the cooling situation, ie when the temperature exceeds $25^{\circ} \mathrm{C}$, the PCM mortars showed a higher heating rate and lower maximum temperature. The same was verified in the heating stage, ie when the temperature is lower than $20^{\circ} \mathrm{C}$, with an increase in the minimum temperature for the PCM mortars, reducing the heating need. When the temperature lies near the indoor thermal comfort zone, the cells exhibit similar temperature values. The effect of heat storage/release is only detected when the temperature diverges from the thermal comfort zone. It was observed a decrease of the maximum temperature higher than 5\% in the cooling situation, and an increase of the minimum temperature higher than $14 \%$ in the heating situation.

During these tests, it was also observed a lag time of the maximum and minimum temperatures higher than 30 min during the cooling situation, and higher than 60 min during the heating situation (Table 3). It is known, that the major part of residential buildings electricity consumption is used for space heating and cooling, varying greatly during the day and night, and leading to differentiated tariffs. Thus, the shift to off-peak periods of this consumption presents a clear economical advantage.

According to Fig. 12, the incorporation of PCM microcapsules into mortars leads to a decrease higher than $11 \%$ in the maximum temperature, and an increase in the minimum temperature higher than $13 \%$, demonstrating that the PCM influences similarly high
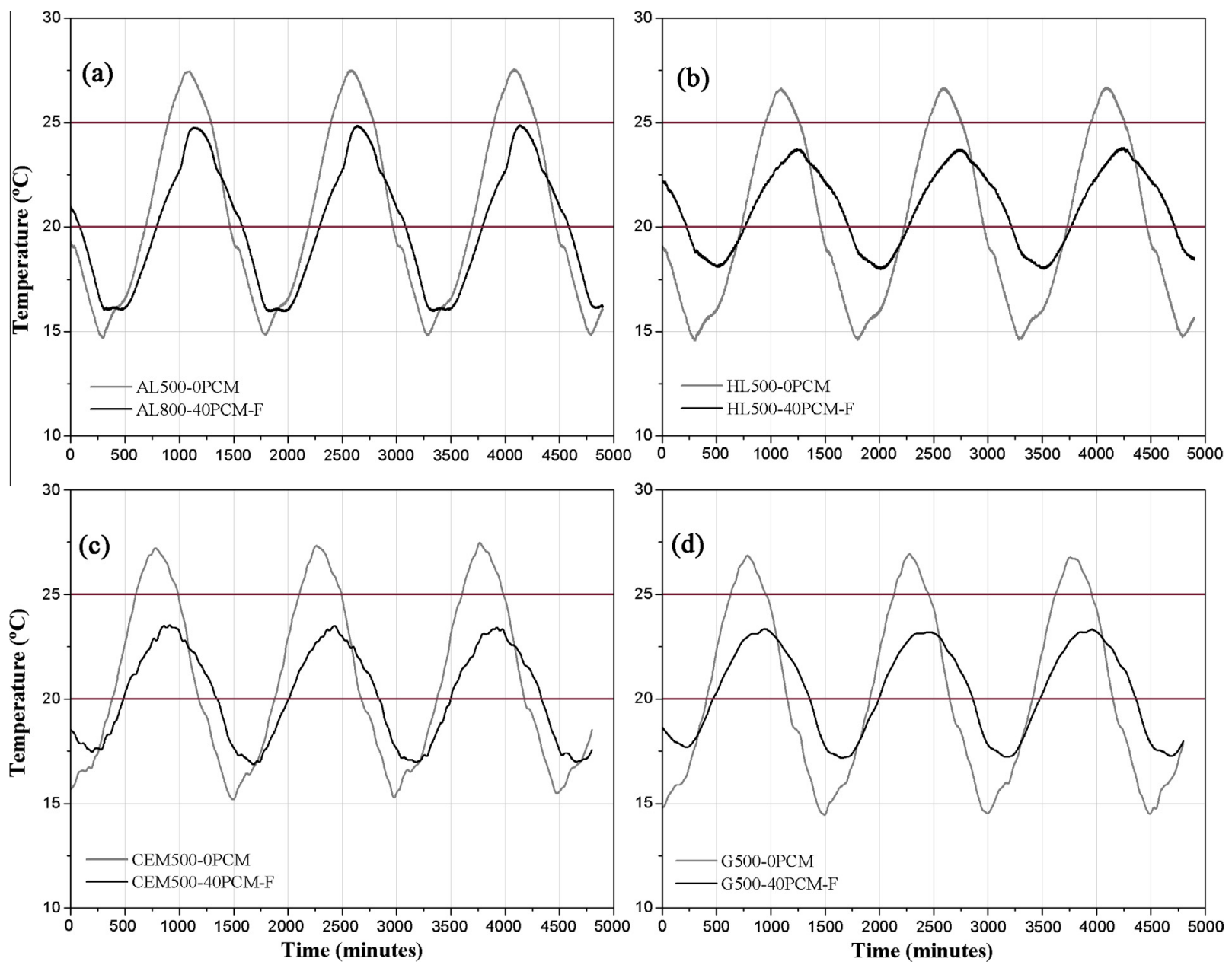

Fig. 12. Thermal behavior in spring of the developed mortars: a) aerial lime mortars, b) hydraulic lime mortars, c) cement mortars, d) gypsum mortars. 

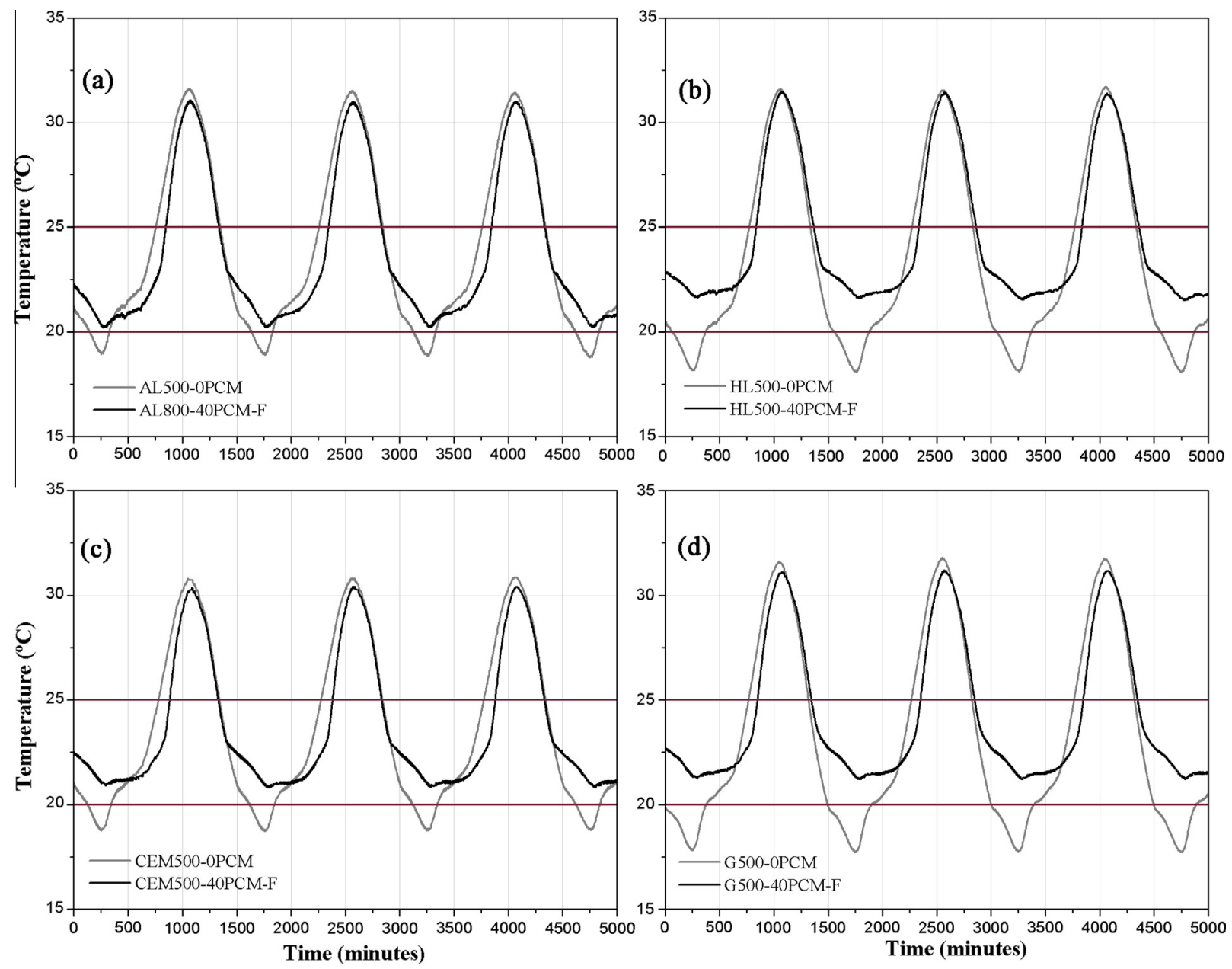

Fig. 13. Thermal behavior in autumn of the developed mortars: a) aerial lime mortars, b) hydraulic lime mortars, c) cement mortars, d) gypsum mortars.

Table 3

Lag time between the maximum and minimum temperatures in summer situation.

\begin{tabular}{llc}
\hline \multirow{2}{*}{ Binder } & Lag time $(\mathrm{min})$ & \\
\cline { 2 - 3 } & Cooling situation & Heating situation \\
\hline Aerial Lime & 55 & 45 \\
Hydraulic Lime & 65 & 125 \\
Cement & 70 & 60 \\
Gypsum & 60 & 95 \\
\hline
\end{tabular}

and low temperatures. It was also detected that the PCM mortars do not present higher temperatures than the maximum comfort temperature $\left(25^{\circ} \mathrm{C}\right)$. Thus, it was verified that it is not necessary to use cooling equipment during the spring season.

Table 4 shows the lag time of the maximum and minimum temperatures verified between the mortars with and without PCM incorporation. It was observed that the lag time of the maximum

Table 4

Lag time between the maximum and minimum temperatures in spring situation.

\begin{tabular}{lll}
\hline Binder & Lag time $(\min )$ & \\
\cline { 2 - 3 } & Cooling situation & Heating situation \\
\hline Aerial Lime & 145 & 80 \\
Hydraulic Lime & 330 & 60 \\
Cement & 250 & 15 \\
Gypsum & 325 & 50 \\
\hline
\end{tabular}

temperature in the cooling situation is higher than $145 \mathrm{~min}$ and the lag time of the minimum temperature in heating situation is higher than 15 min.

Fig. 13 shows the thermal performance of studied mortars in an autumn situation. It was observed that lower temperatures than the comfort temperature of $20^{\circ} \mathrm{C}$ does not exist. This situation means that there is no need to use heating equipment, which leads to a lower energetic consumption in buildings. It was also verified a slight decrease in the maximum temperature and an increase in the minimum temperature higher than $10 \%$. It was also possible to verify that the PCM exhibits a higher influence in the heating situation compared with the cooling situation.

According to Table 5, the lag time of the maximum temperature in the cooling situation is higher than $60 \mathrm{~min}$ and the lag time of the minimum temperature in the heating situation is higher than $200 \mathrm{~min}$.

Table 5

Lag time between the maximum and minimum temperatures in autumn situation.

\begin{tabular}{lll}
\hline Binder & Lag time $(\mathrm{min})$ & \\
\cline { 2 - 3 } & Cooling situation & Heating situation \\
\hline Aerial Lime & 85 & 330 \\
Hydraulic Lime & 60 & 220 \\
Cement & 70 & 335 \\
Gypsum & 45 & 200 \\
\hline
\end{tabular}


The analysis of the obtained experimental temperature curves does not provide enough information about the energy performance of the mortars subjected to heating and cooling cycles. It is necessary to assess the temperature differences within each cell, relative to the reference one $(0 \% \mathrm{PCM})$. This thermal gradient reflects the temperature difference between the cell with PCM mortar and the reference cell without PCM. The thermal gradient was determined in each minute of the thermal test and calculated by the Eq. (1).

$\Delta \mathrm{T}=\mathrm{T}_{\mathrm{REF}}-\mathrm{T}_{\mathrm{PCM}}$

where:

$\mathrm{T}_{\mathrm{REF}}$ - Reference temperature $(0 \% \mathrm{PCM})\left({ }^{\circ} \mathrm{C}\right)$;

$\mathrm{T}_{\mathrm{PCM}}$ - Temperature inside the cell with $\mathrm{PCM}\left({ }^{\circ} \mathrm{C}\right)$.

Fig. 14 shows the variation of the thermal gradient for each composition in each season. As the temperature cycle runs, the thermal gradient increases as a result of the cyclic heat storage process. Hence, the gradient decreases until it reaches the point where the cells are with the same temperature $(\Delta \mathrm{T}=0)$. The gypsum mortars exhibit better thermal regulation with the greater difference in the temperatures observed in all seasons tested. This behavior can be justified with the higher microporosity of these mortars (Fig. 8). The aerial lime mortars exhibit the smaller thermal gradient and consequently the worst thermal performance.
Based on the temperature curves (Figs. 11-13), it was also quantified the reduction of energy consumption during the cooling and heating cycles, with the aim of evaluating the energy saving actually achieved. Thus, the amount of energy exceeding the temperature comfort range during one day was calculated. Thus, it was possible to determine the cooling and heating needs of the buildings to maintain the interior temperature within comfort temperature range, between $20^{\circ} \mathrm{C}$ and $25^{\circ} \mathrm{C}$. Table 6 presents the cooling and heating needs for the different mortars in the different seasons. It was observed that the incorporation of PCM microcapsules into mortars caused a decrease higher than $12 \%$ in the cooling needs and $10 \%$ in the heating needs, in the summer. Regarding the spring situation, it was identified a decrease in the heating needs higher than $7 \%$, with the exception of aerial lime mortars whose values are sensibly constants, and the elimination of the cooling needs. In the autumn situation, it was verified the elimination of heating needs and a decrease higher than $6 \%$ in the cooling needs. Thus, it is possible to verify that the PCM incorporation reduces the cooling and heating needs, in all tested seasons, for all compositions. However, in autumn and spring there are not heating and cooling needs, respectively.

The gypsum mortars exhibited the best thermal regulation, based on the highest thermal gradient, maximum temperature reduction, minimum temperature increase and time delay. This situation can be justified by the higher microporosity (Fig. 8) which improves the temperature regulation effect because there are more
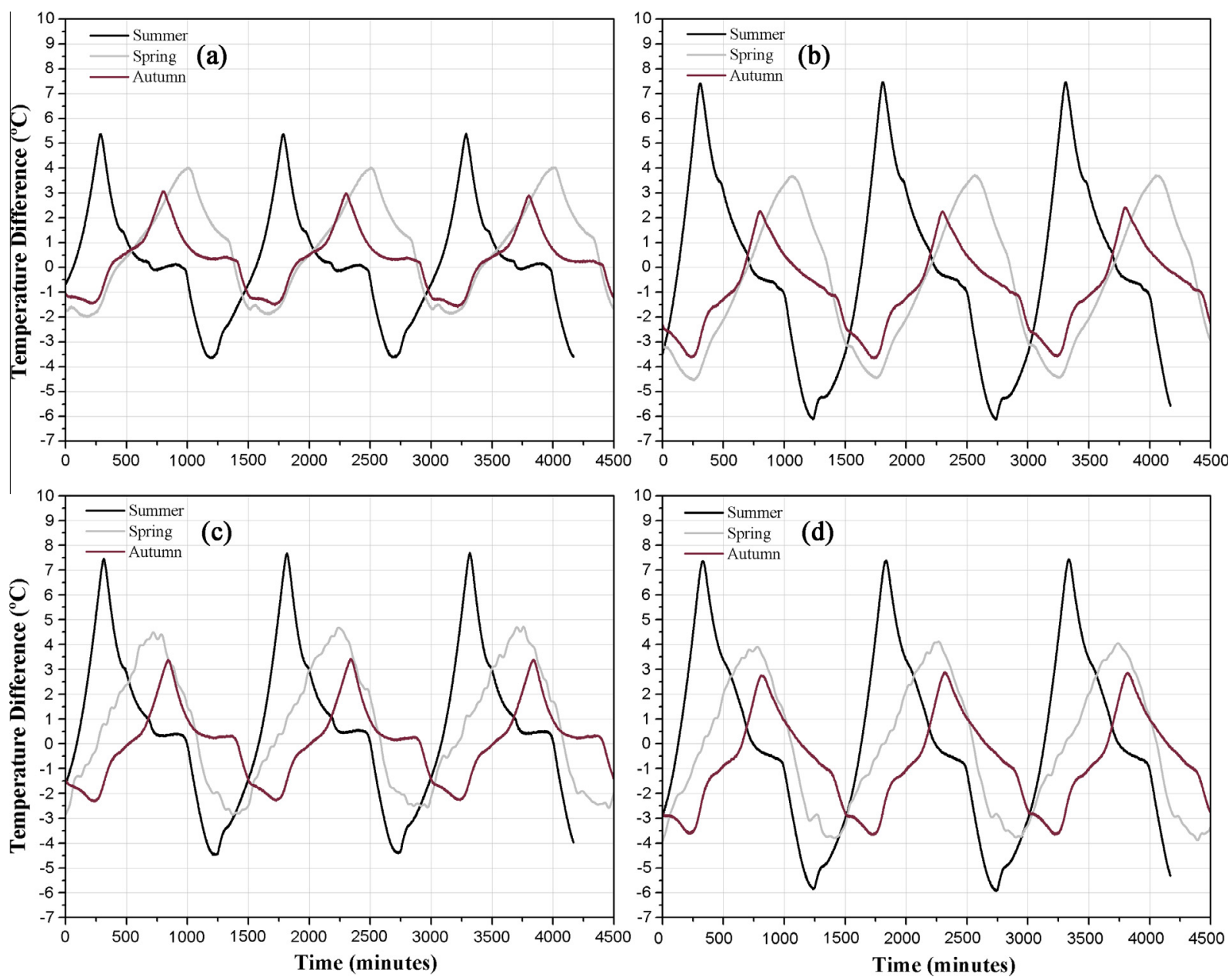

Fig. 14. Thermal gradient: a) aerial lime mortars, b) hydraulic lime mortars, c) cement mortars, d) gypsum mortars. 
Table 6

Cooling and heating needs during one day.

\begin{tabular}{|c|c|c|c|c|c|c|}
\hline \multirow[t]{2}{*}{ Formulation } & \multicolumn{3}{|c|}{ Cooling needs $\left(\mathrm{J} / \mathrm{m}^{3}\right)$} & \multicolumn{3}{|c|}{ Heating needs $\left(\mathrm{J} / \mathrm{m}^{3}\right)$} \\
\hline & Summer & Spring & Autumn & Summer & Spring & Autumn \\
\hline AL500-0PCM & 269,086 & 263,154 & 265,414 & 253,529 & 254,922 & 256,881 \\
\hline AL800-40PCM-F & 238,032 & 0 & 219,013 & 227,959 & 249,786 & 0 \\
\hline HL500-0PCM & 269,831 & 262,696 & 265,457 & 253,074 & 254,714 & 256,549 \\
\hline HL500-40PCM-F & 237,049 & 0 & 249,874 & 188,601 & 180,458 & 0 \\
\hline CEM500-0РCM & 269,598 & 263,040 & 265,014 & 253,509 & 255,061 & 256,811 \\
\hline CEM500-40PCM-F & 225,726 & 0 & 211,723 & 219,089 & 238,647 & 0 \\
\hline G500-0PCM & 269,216 & 262,929 & 277,463 & 253,095 & 254,642 & 256,469 \\
\hline G500-40PCM-F & 217,102 & 0 & 238,747 & 196,061 & 212,588 & 0 \\
\hline
\end{tabular}

PCM microcapsules in contact with the ambient air. The aerial lime mortars revealed the worst thermal behavior, presenting the smallest thermal gradient and lowest extreme temperatures variation. This behavior can be associated to the presence of lower dimensions micropores (Fig. 6).

\section{Cost analysis}

Currently, there is a huge concern with the high energy consumption, verified in the residential sector associated to heating and cooling needs of buildings. The energy used for heating and cooling buildings represents $30 \%$ of the total energy consumption in the different countries of the European Union, or about $75 \%$ of the total energy consumption in buildings [26]. On the other hand, it is expected that the PCM use has a beneficial impact on energy costs, since it allows to reduce the buildings energy needs.

Based on the heating and cooling needs, the energy consumption of the different mortars was calculated. The energy consumption was obtained adding the monthly heating and cooling needs in each season of the year (Table 7). According to the foregoing, for the winter any contribution of the mortars with incorporation of

Table 7

Energy consumption per month $\left(\mathrm{kwh} / \mathrm{m}^{3}\right)$.

\begin{tabular}{llll}
\hline Formulation & Summer & Spring & Autumn \\
\hline AL500-0PCM & 4.36 & 4.32 & 4.35 \\
AL800-40PCM-F & 3.88 & 2.08 & 1.83 \\
HL500-0PCM & 4.36 & 4.31 & 4.35 \\
HL500-40PCM-F & 3.55 & 1.50 & 2.08 \\
CEM500-0PCM & 4.36 & 4.32 & 4.35 \\
CEM500-40PCM-F & 3.71 & 1.99 & 1.76 \\
G500-0PCM & 4.35 & 4.31 & 4.45 \\
G500-40PCM-F & 3.44 & 1.77 & 1.99 \\
\hline
\end{tabular}

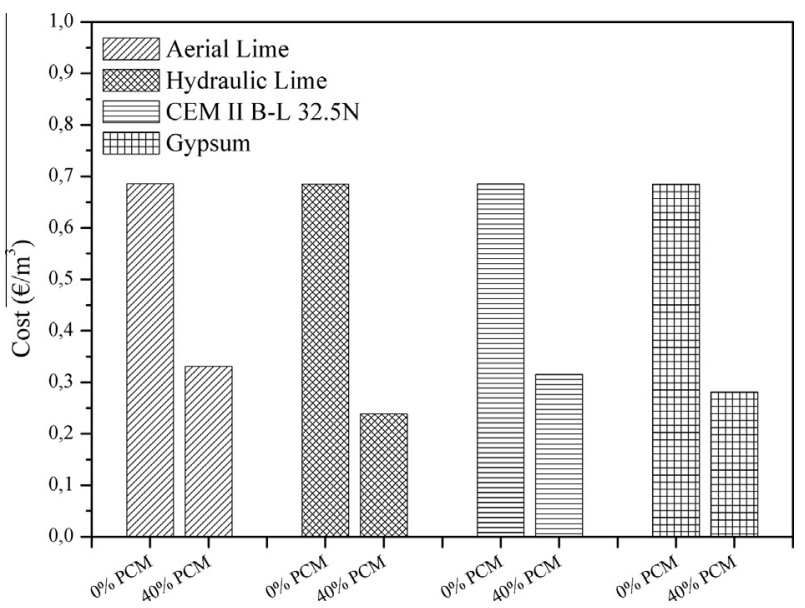

Fig. 15. Cost related to the energy consumption in one typical spring month.
PCM microcapsules was considered, due to the lower typical temperature. The cost of energy consumption in each season was calculated based in energy price in Portugal.

Figs. 15 and 16 shows the cost related to the energy consumption to suppress the heating and cooling needs in typical spring and autumn months, respectively. It was possible to observe that the mortars with incorporation of PCM leads to a cost decrease higher than $52 \%$. Fig. 17 presents the energy consumption cost in a typical summer month. It was verified an energetic costs decrease higher than $11 \%$. As mentioned previously, the energetic cost reduction with PCM mortars is related to its capability to decrease the maximum temperatures, increase the minimum temperatures and consequently decrease the heating and cooling needs, in all tested seasons.

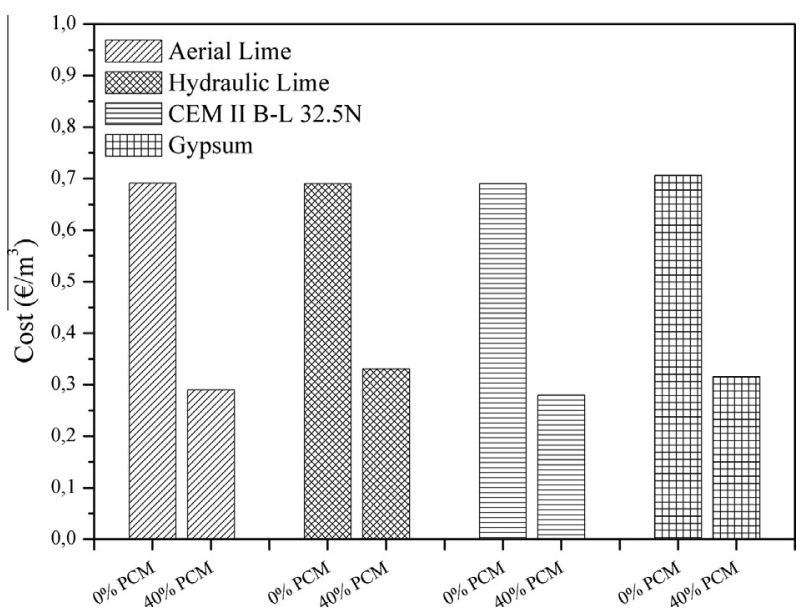

Fig. 16. Cost related to the energy consumption in one typical autumn month.

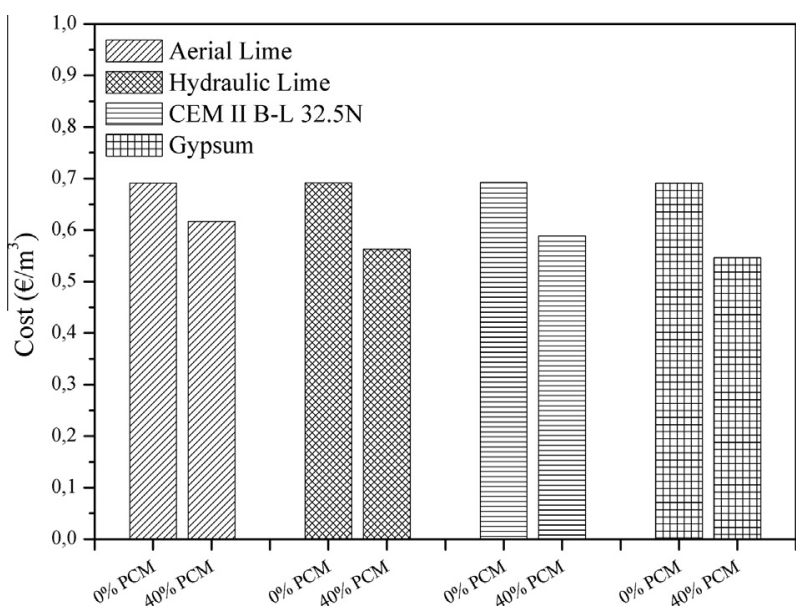

Fig. 17. Cost related to the energy consumption in one typical summer month 
Figs. 15-17 it show that the gypsum mortars have the highest potential for energy saving and consequently the lowest HVAC systems operation cost. This situation can be justified by the highest microporosity (Fig. 8) of these mortars, which improves the contact of the PCM microcapsules with the ambient air.

\section{Conclusion}

This study allowed the comparison of the thermal performance of mortars prepared using PCM microcapsules and different binders. The workability, flexural strength, compressive strength, microstructure and costs of the developed mortars were also evaluated.

The incorporation of PCM caused an increase in the amount of water added to the mortars in order to achieve a suitable workability. This is related with the fineness of the PCM microcapsules. The evaluation of the mechanical strengths showed a decrease in the flexural and compressive strengths with the incorporation of PCM microcapsules, which is a consequence of the higher water/ binder ratio. However, it was possible to always maintain a strength class that will guarantee a good behavior of the mortars in the construction sector.

It was possible to identify a good interaction between the mortars constituents materials, evidenced by the absence of cracks in the microstructure of the developed mortars. It was also observed a good resistance of the PCM microcapsules to the mixture procedure, evidenced by the absence of damaged PCM microcapsules. It was also observed that the incorporation of PCM microcapsules leads to an increase in the microporosity for all tested binders. This situation can be justified by the increase of the water content of the mortars doped with PCM, due to the fineness characteristics of this material.

The incorporation of PCM microcapsules leads to a decrease of the maximum temperatures higher than $5 \%$ and an increase in the minimum temperatures higher than $10 \%$. It was also verified a lag time delay of extreme temperatures higher than $30 \mathrm{~min}$ in the cooling situation and higher than 15 min during the heating situation. It was also possible observe that the mortars with PCM do not present temperatures higher than the maximum comfort temperature $\left(25^{\circ} \mathrm{C}\right)$ in the spring season and temperatures lower than the minimum comfort temperature $\left(20^{\circ} \mathrm{C}\right)$ in the autumn season. Thus, it will not be necessary the use of cooling equipment during the spring season and heating equipment during the autumn season. These results allow to conclude that the utilization of PCM in interior coating mortars can reduce the energetic consumptions, reducing the energy demand, the fossil fuel depletion and the environmental impact associated with the heating and cooling systems.

The gypsum mortars exhibited a better thermal regulation, based on the highest reduction of the maximum temperature, highest increase of the minimum temperature, most significant lag time delay and consequently lowest heating and cooling needs. This situation can be justified by the highest microporosity of these mortars, which improves the temperature regulation effect because there are more PCM microcapsules in contact with the ambient air. On the other hand, the aerial lime mortars presented the worst thermal behavior, with the lowest variation in the extreme temperatures, and highest heating and cooling needs. This behavior can be associated to the presence of lower dimensions micropores.

The cost analysis showed that the incorporation of the PCM microcapsules in mortars leads to a decrease in the energy consumption cost in the spring, autumn and summer, due to the decrease of heating and cooling needs, and consequently decrease of HVAC systems operation.

\section{Acknowledgement}

The authors acknowledge the Portuguese Foundation for Science and Technology (FCT) for the financial support of $\mathrm{PhD}$ scholarship SFRH/BD/95611/2013.

\section{References}

[1] S. Bilgen, Structure and environmental impact of global energy consumption, Renewable Sustainable Energy Rev. 38 (2014) 890-902.

[2] N. Soares, J. Costa, A. Gaspar, P. Santos, Review of passive PCM latent heat thermal energy storage systems towards buildings energy efficiency, Energy Build. 59 (2013) 82-103.

[3] I. Santiago, M.A. Lopez-Rodriguez, D. Trillo-Montero, J. Torriti, A. MorenoMunoz, Activities related with electricity consumption in the Spanish residential sector: variations between days of the week, autonomous communities and size of towns, Energy Build. 79 (2014) 84-97.

[4] M. Diamanti, M. Ormellese, M. Pedeferri, Characterization of photocatalytic and superhydrophilic properties of mortars containing titanium dioxide, Cem. Concr. Res. 38 (2008) 1349-1353.

[5] G. Blengini, T. Carlo, The changing role of life cycle phases, subsystems and materials in the LCA of low energy buildings, Energy Build. 42 (2010) 869-880.

[6] S. Cunha, J. Aguiar, M. Ferreira, A. Tadeu, Influence of the type of phase change materials microcapsules on the properties of lime-gypsum thermal mortars, Adv. Eng. Mater. 16 (2014) 433-441.

[7] S.A. Memon, Phase change materials integrated in building walls: a state of the art review, Renewable Sustainable Energy Rev. 31 (2014) 870-906.

[8] D.W. Hawes, D. Banu, D. Feldman, Latent heat storage in concrete, Solar Energy Mater. 19 (1989) 335-348.

[9] G. Fang, F. Tang, L. Cao, Preparation, thermal properties and applications of shape-stabilized thermal energy storage materials, Renewable Sustainable Energy Rev. 40 (2014) 237-259.

[10] L. Cabeza, A. Castell, C. Barreneche, A. Gracia, A. Fernández, Materials used as PCM in thermal energy storage in buildings: a review, Renewable Sustainable Energy Rev. 15 (2011) 1675-1695.

[11] V. Tyagi, S. Kaushik, S. Tyagi, T. Akiyama, Development of phase change materials based microencapsulated technology for buildings: a review, Renewable Sustainable Energy Rev. 15 (2011) 1373-1391.

[12] L. Shilei, Z. Neng, F. Guohui, Impact of phase change wall room on indoor thermal environment in winter, Energy Build. 38 (2006) 18-24.

[13] K. Darkwa, P. O'Callaghan, D. Tetlow, Phase-change drywalls in a passive-solar building, Appl. Energy 83 (2006) 425-435.

[14] P. Schossig, H. Henning, S. Gschwander, T. Haussmann, Micro-encapsulated phase change materials integrated into construction materials, Solar Energy Mater. Solar Cells 89 (2005) 297-306.

[15] M. Ahmad, A. Bontemps, H. Sallée, D. Quenard, Thermal testing and numerical simulation of a prototype cell using light wallboards coupling vacuum isolation panels and phase change material, Energy Build. 38 (2006) 673-681.

[16] S. Cunha, V. Alves, J.B. Aguiar, V.M. Ferreira, Use of phase change materials microcapsules in aerial lime and gypsum mortars, Cem. Wapno Beton (Special Issue) (2012) 17-21.

[17] S. Cunha, J.B. Aguiar, V.M. Ferreira, A. Tadeu, Influence of adding encapsulated phase change materials in aerial lime based mortars, Adv. Mater. Res. 687 (2013) 255-261.

[18] S. Cunha, J.B. Aguiar, V.M. Ferreira, A. Tadeu, Mortars based in different binders with incorporation of phase change materials: physical and mechanical properties, Eur. J. Environ. Civil Eng. 19 (2015) 1216-1233.

[19] European Committee for Standardization (CEN), EN 1015-3:2004, Methods of Test for Mortar for Masonry - Part 3: Determination of Consistence of Fresh Mortar (by Flow Table), 2004.

[20] European Committee for Standardization (CEN). EN 1015-11:1999, Methods of Test for Mortar for Masonry - Part 11: Determination of Flexural and Compressive Strength of Hardened Mortar, 1999.

[21] M. Kheradmand, J. Aguiar, M. Azenha, Assessment of the thermal performance of plastering mortars within controlled test cells, in: Luso-Brazilian Conference on Sustainable Construction Materials, 5-7 de Março, Guimarães, Portugal, 2014.

[22] Portuguese Institute for Quality (IPQ), NP EN 998-1:2013, Specification for Masonry Mortars - Part 1: Plastering Mortars for Interior and Exterior, 2013 (in Portuguese).

[23] A. Khudhair, M. Farid, A review on energy conservation in building applications with thermal storage by latent heat using phase change materials, Energy Convers. Manage. 45 (2004) 263-275.

[24] J. Li, P. Xue, H. He, W. Ding, J. Han, Preparation and application effects of a novel form-stable phase change material as the thermal storage layer of an electric floor heating system, Energy Build. 41 (2009) 871-880.

[25] V. Hernández, D. Morillón, R. Best, J. Fernández, R. Almanza, N. Chargoy, Experimental and numerical model of wall like solar heat discharge passive system, Appl. Therm. Eng. 26 (2006) 2464-2469.

[26] H. Tommerup, S. Svendsen, Energy savings in Danish residential building stock, Energy Build. 38 (2006) 618-626. 